HONEY

I)

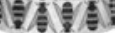





\section{Fireflies, Honey, and Silk}

G I L B E R T W L D B A U E R

WITH ILLUSTRATIONS BY JAMES NARDI

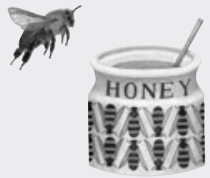

廿 University of California Press Berkeley Los Angeles London 
The publisher gratefully acknowledges the generous support of the General Endowment Fund of the University of California Press Foundation.

University of California Press, one of the most distinguished university presses in the United States, enriches lives around the world by advancing scholarship in the humanities, social sciences, and natural sciences. Its activities are supported by the UC Press Foundation and by philanthropic contributions from individuals and institutions. For more information, visit www.ucpress.edu.

University of California Press

Berkeley and Los Angeles, California

University of California Press, Ltd.

London, England

(C) 2009 by Gilbert Waldbauer

Illustrations (C) 2009 by James Nardi

Library of Congress Cataloging-in-Publication Data

Waldbauer, Gilbert.

Fireflies, honey, and silk / Gilbert Waldbauer. With illustrations by James Nardi.

p. $\mathrm{cm}$.

Includes bibliographical references and index.

ISB N 978-0-520-25883-9 (cloth: alk. paper)

1. Beneficial insects. I. Title.

SF517.W35 $2009 \quad 2008047713$

$595.7^{\prime} 163-\mathrm{dc} 22$

Manufactured in the United States of America

$\begin{array}{llllllllll}18 & 17 & 16 & 15 & 14 & 13 & 12 & 11 & 10 & 09\end{array}$

$\begin{array}{llllllllll}10 & 9 & 8 & 7 & 6 & 5 & 4 & 3 & 2 & 1\end{array}$

The paper used in this publication meets the minimum requirements of ANSI/NISO Z39.48-1992 (R 1997) (Permanence of Paper). 
To John Henry Comstock of Cornell University, the father of academic entomology, and to his wife, Anna Botsford Comstock, who pioneered the teaching of nature study at Cornell 
This Page Left Intentionally Blank 